\title{
19. Role of MNEs in building zero waste communities
}

\section{Suraksha Gupta}

\subsection{INTRODUCTION}

MNEs are accused by social development scholars of exploiting the vulnerability of developing countries for profit. Developing countries suffer from a lack of regulations, infrastructure and know-how required for development. The absence of resources, regulations, technical know-how and required infrastructure slows down the pace of development and expands the scope of exploitation by MNEs and the progression of the poor towards higher levels of poverty (Spence, 2008). Stakeholders are holding companies responsible and accountable for the impact of their activities on the wellbeing of self and communities. Local residents in communities in which international companies operate are influenced by the after-effects of their activities. One of the unforgettable examples is the case of Union Carbide and the leakage of gas from its factory in Bhopal, India, which has created health issues for generations of families living in the city and nearby areas. Such issues raise concerns in the local stakeholder communities about the inefficient creation and management of waste. Years of hazardous waste along with inefficient management, combined with the exploitation of regulatory gaps in developing countries by MNEs, are being termed by stakeholders as "toxic terrorism by MNEs" to the very end of the supply chain by training and monitoring the wasterelated activities of actors at the ground level. The purpose of this study is to reflect on practices and strategies that will enable MNEs to penetrate and push environmentally friendly zero waste practices. To achieve the objective of providing direction to the managers of MNEs, the reflections of previous scholars in the extant literature on waste management issues such as strategy, operational issues, corruption, etc., have been reviewed in Table 19.1.

Although reports are critical of mining industries being set up in developing countries by companies in developed markets, one of the major financiers of large mining set-ups is the World Bank. Outcomes such as 
Table 19.1 A review of the literature

\begin{tabular}{|c|c|c|}
\hline Author/s & Study type & Focus of the study \\
\hline $\begin{array}{l}\text { Rugman and } \\
\text { Verbeke (2000) }\end{array}$ & $\begin{array}{l}\text { Case study } \\
\text { analysis }\end{array}$ & $\begin{array}{l}\text { Resource-based perspective on green strategies } \\
\text { can help MNEs develop either localized or } \\
\text { internationally transferable green capabilities } \\
\text { related to waste management and landfills }\end{array}$ \\
\hline $\begin{array}{l}\text { Boylan and } \\
\text { Russell (2006) }\end{array}$ & $\begin{array}{l}\text { Case study } \\
\text { analysis }\end{array}$ & $\begin{array}{l}\text { Recognize the extent to which MNEs operating } \\
\text { in resource-rich developing countries contribute } \\
\text { to sustainable development }\end{array}$ \\
\hline $\begin{array}{l}\text { Delmas and } \\
\text { Toffel (2008) }\end{array}$ & $\begin{array}{l}\text { Survey and } \\
\text { archival data } \\
\text { analysis }\end{array}$ & $\begin{array}{l}\text { Adoption of environmental management } \\
\text { practices based on impact of interaction } \\
\text { of external constituents with corporate } \\
\text { departments }\end{array}$ \\
\hline Rug & & Analyze green capabilities of MNEs using \\
\hline Verbeke (19 & & $\begin{array}{l}\text { firm-specific and country-specific advantages } \\
\text { to understand interaction between firm-level } \\
\text { competitiveness and environmental regulations }\end{array}$ \\
\hline Matten (2004) & $\begin{array}{l}\text { Reflective } \\
\text { study }\end{array}$ & $\begin{array}{l}\text { Role of government and social actors in helping } \\
\text { corporates address risks of globalization in } \\
\text { relation to waste management systems and } \\
\text { regulation }\end{array}$ \\
\hline $\begin{array}{l}\text { Genovese et al. } \\
\text { (2013) }\end{array}$ & $\begin{array}{l}\text { Empirical } \\
\text { study }\end{array}$ & $\begin{array}{l}\text { Review of waste management studies to } \\
\text { understand penetration of environmental and } \\
\text { green criteria and selection of green suppliers by } \\
\text { corporates }\end{array}$ \\
\hline $\begin{array}{l}\text { Nigh and } \\
\text { Cochran } \\
\text { (1994) }\end{array}$ & $\begin{array}{l}\text { Reflective } \\
\text { study }\end{array}$ & $\begin{array}{l}\text { Differences in strategies of multinational } \\
\text { and uninational enterprises for managing } \\
\text { responsibilities with key constituencies by } \\
\text { engaging issue managers, such as Issue Manager, } \\
\text { Waste Management }\end{array}$ \\
\hline $\begin{array}{l}\text { Curran and } \\
\mathrm{Ng}(2018)\end{array}$ & $\begin{array}{l}\text { Qualitative } \\
\text { study }\end{array}$ & $\begin{array}{l}\text { Study of two waste management consultancy } \\
\text { firms to recognize capability of firm-specific } \\
\text { advantage of European MNEs to underline } \\
\text { international expansion in emerging markets }\end{array}$ \\
\hline $\begin{array}{l}\text { Maleka et al. } \\
\text { (2017) }\end{array}$ & $\begin{array}{l}\text { Empirical } \\
\text { study }\end{array}$ & $\begin{array}{l}\text { Impact of waste management expenditure and } \\
\text { waste management targets on firm's profitability }\end{array}$ \\
\hline
\end{tabular}

displacement, inequality and social tension as the major effects of mining operations in resource-rich extremely poverty-stricken areas have been reported to be directly responsible for a deterioration in the quality of life of the poor in countries like Peru and Tanzania. Although international companies commit to adhere to rigorous regulations and protection rules 
of their host country, they often fail to follow them. As a result, we have examples of hazardous material affecting the health of people living in local communities, such as adults and children living in the mining area of Peru having traces of lead in their blood. Despite being profit-rich industries the wages paid to local workers are very basic and they lack any benefits of employment. The charity War on Want, working on poverty issues, reported that mining companies in Ghana pay only 0.5 percent of the value of the minerals being extracted towards local community projects. The incident of a civilian being killed and others injured in Ghana in 2005 - while protesting against the mining activities of MNEs because of the resultant losses to farmers in the local community - reflects the seriousness of conflict between the two. Stakeholders have been expressing their concerns about the exploitative practices of particularly the oil, gas and mining industries. Issues related to environmental and climate change - in addition to the damage to health combined with violations of human rights - have pushed poor people engaged in mining activities into deeper poverty, and the poor state of governance in developing countries has resulted in an increase in corruption. Due to corruption and lax regulations in developing countries, toxic waste generated from mining is dumped into rivers, which leads to water contamination and results in diseases like cancer.

Of the 1.3 billion tons of waste generated every year by consumers around the world, 44 percent of this waste is generated in OECD countries (Koop and van Leeuwen, 2017; Zorpas et al., 2017). The United Nations issued a warning that the global volume of waste related to electronic devices containing toxic substances was expected to grow by 33 percent by 2017 , waste that developed countries would be unable to dispose of (The Guardian, 2013). Currently, the e-waste generated by consumers in developed countries from electronic appliances such as mobile phones, washing machines, refrigerators, computers and televisions etc., is higher in comparison to developing countries (Zeng et al., 2017). For example, e-waste generated by the UK recently amounted to 1.37 million tons (Guardian Weblink 1, 2013). Therefore, developed markets are transferring non-functional waste material to developing countries for refurbishment and reuse, which is being sold on to the informal sector for further treatment at a lower cost than for legitimate recycling (Arora, 2008). Upon reaching landfills such recycled products cause health-related risks for local residents in developing countries with contamination of land, water and air (Frazzoli et al., 2010). A circular package proposed by the European Commission in December 2015 pushed extended producer responsibility (EPR) schemes for the identification and treatment by manufacturers of products at the end of their lifecycle. This scheme led to the meeting of waste management targets by member states. 
A circular package refers to a regenerative economy that is based on the philosophy of maximizing value utilization innovatively at every stage of the lifecycle of a product by designing products that are restorative and regenerative, with an aim to create economic capital, social capital and natural capital. Based on this school of thought, the circular economy involves product design to consider material that can later be segregated into by-products and waste. Hence, it is anticipated that material used by a circular economy will reduce waste. Management of the share of municipal waste for reuse and recycling during the lifecycle of the product is anticipated to grow by 2025 (60 percent) and 2030 (65 percent) (Tisserant et al., 2017). The assessment procedures adopted during the lifecycle by MNEs transporting material across national borders aid the estimation of the burden levied by the packaging of a product on the environment. The International Organization for Standardization (ISO) provides officially identified and regulated standards to be used at different levels by an international organization, such as operational performance and strategic management performance. These indicators push organizational efforts through customer education, supply chain and logistics orientation with asset and social orientation.

Scholars such as Tojo and Hansson (2004) reported four types of waste management practices followed internationally by different countries: (1) informative, (2) administrative, (3) economic and (4) legal. Informative management practices make all stakeholders aware of their role and contribution in waste management. These practices require organizations to be conscious of the waste their product produces. In this context, the quantity and type of waste produced is reported by companies to their stakeholders as part of highlighting their responsibility, and waste recyclers are trained in recycling skills by the government concerned. Simultaneously, these practices keep consumers informed about processes to be adopted to separate waste or about recycling initiatives taken by firms to recycle the waste produced by consumers, thereby making consumers conscious of the waste they produce. Administrative practices are generally voluntarily adopted practices by firms, wherein organizations incorporate waste management into their promotional schemes, to trace and retrieve their waste packaging after consumption. These practices incentivize supply chain partners to innovatively adhere to landfill restrictions based on the theory of means and ends. The engagement of dedicated managers through administrative practices makes the collection, reuse and recycling of waste efficient, by following scientifically recommended packaging standards while identifying the material used in order to standardize and adapt packaging strategies in different markets. Economic practices encourage incentivization on reducing waste, through financial engagement in advance of waste 
generation. Some of these engagements involve taking a deposit that is refundable or charging an advance disposal fee on the weight of the material being supplied. Countries which have become highly conscious of the waste they produce have incorporated a legal aspect in their waste management practices through obligatory regulations about shared cost of waste management between various types of stakeholders such as manufacturers, local municipalities and consumers (Table 19.2).

However, the dark side of waste management restricts companies from engaging themselves actively in waste-related practices. Hence, companies generally prefer to work with third-party organizations to fulfill their responsibility. One such example is the failure of a high-technology waste treatment plant built by Grasim Industries in Jaipur, India, during 2007, under a 30-year public-private contract with the government to produce refuse-derived fuel from the municipal waste. Unfortunately, this plant did not show effective results and suffered losses due to corruption and poverty in the segment that provided services to this sector. Despite multiple contracts signed by local authorities, and efforts by NGOs to facilitate the door-to-door collection of garbage in the city and the transportation of waste to the disposal site at a very minimal cost to the user of the service, the project was a failure. Another challenge for this project was related to issues of corruption in the management of timely collection and submission of payment. Such operational expenses for NGOs and profitability for the corporate sector become the demotivating factors that discourage them from participating in such initiatives (Cetindamar, 2007). Although the use of public-private partnerships (PPPs) for the management and conversion of waste has been successful in cities such as Mumbai and Delhi, it has failed in small cities such as Jaipur.

The proposal of EPR is expected to create jobs, avoid greenhouse emission and improve recycling of waste through the introduction of a waste hierarchy that aids waste prevention, avoids contamination and promotes reuse by creating a platform for a shared economy, for the betterment of human and environmental health (Weblink 2). However, the big challenges facing a circular economy are consumer behavior, recycling habits, recycling skills and the business models managers adopt to incorporate the fundamentals of recycling into their operations and everyday business activities, in addition to a lack of efficient governance at multiple levels including upstream, midstream and downstream levels (Vezzoli et al., 2015). This chapter aims to reflect on the business practices and business requirements of MNEs historically and in the current context, with the objective of proposing the integration of concepts of waste management into MNEs' business policy. The following section discusses the history of waste management practices followed by their connection with corruption 
Table 19.2 Practices and management strategies for waste management adopted by MNEs in various countries

\begin{tabular}{lll}
\hline Practice type & Management philosophy & Countries adopting \\
\hline Informative & $\begin{array}{l}\text { Educate to raise } \\
\text { consciousness }\end{array}$ & $\begin{array}{l}\text { Australia, Belgium, Finland, } \\
\text { Germany, etc. }\end{array}$ \\
Administrative & Voluntary approach & $\begin{array}{l}\text { Malaysia, Thailand, South } \\
\text { Africa, Iceland, etc. }\end{array}$ \\
& & $\begin{array}{l}\text { Portugal, Poland, Norway, } \\
\text { Economic }\end{array}$ \\
Liability approach & $\begin{array}{l}\text { Bulgaria, Japan, etc. } \\
\text { Legal }\end{array}$ & Regulatory approach \\
& & Croatia, Denmark, etc. \\
\hline
\end{tabular}

in a circular economy and a discussion on the role of marketing in managing waste and contributing towards the creation of a circular economy.

\subsection{A HISTORY OF WASTE MANAGEMENT}

Early in the nineteenth century in England, Sir Edward Chadwick noticed how desire for a clean and healthy environment leads to the accumulation of filth and drew upon needed reforms in public health and sanitation by introducing Sanitary Science to the public administration authorities (Kearns, 1988). He drew upon the responsibility of the government to manage the sanitation and health of its population after a severe outbreak of Cholera in 1848, after which the first Public Health Act was introduced in the UK (Hamlin, 1998). This act passed the responsibility of improving drainage, sewers, water supplies, the removal of garbage from homes to landfills and paying for medical facilities to local councils (Louis, 2004). Some councils such as Sunderland (in England) assumed the responsibility and Swansea (in Wales) built a sewerage system (Bell and Millward, 1998). Simultaneously, the Artisans' and Labourers' Dwelling Improvement Act enforced the engagement of local councils or municipalities in these reforms through improved town planning with efficient management of landfills (Aoki, 1992). Today, with 650 million cubic meters of landfill capacity, with 450 mechanical treatment plants and two landfill tax rates i.e. GBP2.80 and GBP88.95 per ton based on the ability to degrade - the UK is expected to run out of its capacity to manage landfill waste by 2023 .

The landfill tax was introduced by the UK government in 1996 to reduce the amount of waste being sent to landfill (Sealey et al., 2001). Today, the waste management industry retrieves the tax from consumers, 
and councils from their residents, by charging proportionately more for the amount of waste thrown into bins (Vergara and Tchobanoglous, 2012). Waste collected is thrown into landfills, which become the cause of hazardous pollutants like leachate and landfill gas (Singh et al., 2011). Therefore, waste management has moved from being an issue far beyond the role of municipalities to being a bottom-up and top-down approach that requires resources for avoiding the generation of waste (Kemp et al., 2007). The lack of capacity in landfills in developed countries has led to an increase in the global trade in waste, including the transportation of hazardous materials from developed countries to developing countries in the name of treatment, disposal and recycling (Ongondo et al., 2011). This has increased the creation of illegal waste dumping sites in developing countries. Interpol has revealed that one in three containers leaving Europe contains illegal e-waste (Guardian Weblink 1).

\subsection{MANAGING WASTE FOR A CIRCULAR ECONOMY}

The circular economy package proposed by the EU includes four legislative proposals: (1) a waste directive framework; (2) a landfill directive; (3) a packaging directive; and (4) a directive of end-of-life products and equipment including batteries, vehicles, electrical and electronic equipment (Otles et al., 2015). Europe has been a leading steward of waste management since 2003, through the Waste from Electrical and Electronic Equipment (WEEE) directive, aimed at reducing electrical and electronic waste that ends up in landfills (Sthiannopkao and Wong, 2013). It also requires producers of a wide range of electronic devices to create a convenient system of collection of products that have reached the end of their lifecycle, for the purpose of recycling (Goosey, 2004). The waste directive framework provided guidelines and directions for corporations to follow for incorporating waste management into the cost of their product, by identifying a waste hierarchy model for prevention plans with the strategic management of waste using a topdown approach that begins with prevention and passes through the stages of preparation for reuse, recycling and recovery of energy before disposal (Kuo et al., 2001). It also reflects on the EPR framework which requires manufacturers to responsibly manage their supply chain in a way that allows the efficient collection, sorting and treatment of used goods for recycling (de Oliveira et al., 2012). Although managing waste is not a pleasant activity, the regular and efficient monitoring, management and control of domestic and industrial disposals is very important for the reduction of its effect on environmental and human health (Rushbrook and Finnecy, 1988). 
The landfill directive issued in the year 1999 banned the disposal of untreated waste into landfills and gradually identified the amount of biodegradable waste that could be disposed in a landfill in the member states of Europe (Williams, 2005). The focus of the packaging directive established in 1994 was on the impact of the operationalization of businesses on the reduction of waste that is hazardous to the environment (Dechant and Altman, 1994). Its aim was to encourage the intervention of the state into business operations in order to reduce the waste related to the packaging of products being sold in consumer markets, through recovery and recycling (Coelho et al., 2011). The fourth directive for a circular economy is for controlling waste from end-of-life vehicles, batteries and accumulators and waste electrical and electronic equipment (WEEE), by implementing a "fitness report" system for vehicles, controlling the amount of hazardous material in batteries and accumulators with WEEE (Turunen, 2017). It is anticipated that the circular economy package with management and monitoring of its four directives, by clarifying the methods that corporations can use to calculate their contribution towards the building of a circular economy and enabling public authorities to report and evaluate the quality of action taken by corporations, can improve economic and environmental wellbeing and reduce the cost of waste management for public authorities and consumers, by using indicators of resource efficiency (Milios, 2017).

These initiatives have raised the level of targets being identified for the management of waste and have strengthened the implementation capacity of MNEs, by engaging different stakeholders (Fox et al., 2002). But these developments have still not been able to engage and motivate managers managing global supply chains at the field level in the consumer markets of developing countries to incorporate waste management concepts into their business practices (Jenkins, 2006). MNEs need to develop business models that will be used by their managers to incorporate waste management into their business practices in developing markets by using the bottom-up and top-down approaches (Tseng et al., 2013). They should take up initiatives such as educating consumers about the segregation of waste and degradable packaging material, and using strategic alliances innovatively to reduce waste generation, etc., especially for developing countries (Popper et al., 2017). Such initiatives will contribute to the development of smart cities in developing countries like India, wherein waste today is disposed of and dumped in open areas which impacts the environment by contaminating the ground surface and polluting water, and produces noxious air pollution, in addition to greenhouse gas emission and the breeding of insects that spread diseases (Parashar, 2016). The concept of a circular economy promotes the reduction of waste and increased resource productivity with 
reduced environmental impact, making the economy competitive through models of recovery and regeneration. However, current understanding about this is very limited (Hu et al., 2011).

In many of the small cities in developing countries such as India there are no technologically developed landfill areas (Shekdar, 2009). Waste is collected and disposed of in these cities through a system of bins and, after collection, contractors transport waste by road to the dumping sites (Sharholy et al., 2008). These contractors make a concerted effort to dump waste in a cost-effective manner, which unfortunately turns out to be highly unscientific in nature (Sharholy et al., 2008). Overall, the system of waste management in developing countries suffers from limitations such as a lack of commitment on the part of the government, which increases the corruption and power of the unorganized sector (Reich, 1995). Despite the use of technology for transparency and the support of PPPs for the treatment or commercialization of waste -either by converting waste into compost or energy - only one in three landfills in small cities is scientifically equipped to restrict the seepage of hazardous material from waste into the soil (Asnani, 2006). Waste management currently also suffers from other management issues such as irregularities in the use of public spaces for the improper dumping of waste, spitting, urination or defecation; encroachment by shopkeepers or hawkers; parking of vehicles; or the non-availability of manpower that has an understanding of waste management and is motivated to perform their duties, despite the use of biometric devices for monitoring their attendance (Mahongano, 2017).

\subsection{MARKETING FOR BUILDING ZERO WASTE COMMUNITIES}

Consumers around the world today use many products packaged beautifully in different types of packaging (Silayoi and Speece, 2004). When products reach the end of their lifecycle they need to be disposed of, and the waste produced from their disposal needs to be managed properly by local municipalities because of the toxins they might contain or the greenhouse gases that might be produced that would pollute water and air in the locality (Ngoc and Schnitzer, 2009). As a result, local municipalities have been spending taxpayers' money to manage waste that is detrimental to environmental, social and economic wellbeing (de Araújo and Costa, 2006). The concerns of municipalities in developed countries related to the sourcing and transformation of waste, and its disposal system, have over the years led them to send their waste to developing markets on the pretext of recycling. The Chinese authorities' recent ban on the supply of waste 
inside China has pushed many countries to reconsider their waste management strategies and restrict the dumping of their waste in developing countries. Furthermore, international law now regulates the disposal of waste. The International Solid Waste Association (ISWA) promotes a professional approach to the sustainable management of waste worldwide. ISWA plays an active role in informing international companies about the effect on the environment of the waste they produce and the legal implications of disposing of waste. It also engages itself in helping companies audit the waste they produce and motivate senior management in the organizations towards committing and championing waste reduction. Engaging senior managers in the creation of an action plan for managing waste across national borders creates stronger emotional bonds with stakeholders.

Waste from households, commercial set-ups, and clinical and industrial waste classified as controlled waste combined and non-controlled waste that comes in the form of agricultural waste, radioactive and explosive waste are both hazardous in nature. It is challenging for international companies to manage hazards from waste through a recycling approach. MNEs focus on materials with efficient use of technology and operational practices in their international business strategies, which promote waste reduction and recycling. But it is difficult for them to implement strategies that will enable them to manage waste as a by-product or substitute of the raw material from the original process, because these efforts will require an efficient design that allows reverse logistics. The implementation of a reverse logistics strategy calls for strategic interventions to bring changes in the product and their substitution to develop conservation and composition capability. The implementation of a combination of these elements voluntarily by managers in their international business strategies will be successful when the philosophy of waste control is implemented at the initial stage of procurement. Hence, in procuring for their international products it becomes important for companies to review the waste a proposed material will generate, with regulatory and operational support available from the local municipalities, which will facilitate efficient waste management processes for MNEs.

The optimization of resources and the management of waste needs the engagement of stakeholders through public education, unit pricing inclusive of a disposal management fee, the identification of standards for recycling and disposal to landfills, the implementation of recycling processes within production system and closed loop recycling (Hume, 2014). At the same time, transformation requires the integration of a product stewardship strategy with extended producer responsibility (Toffel, 2003). Therefore, managers of MNEs should work with their suppliers at the design stage to explore the efforts and investments required in different regions to 
manage the waste that it would create. For this, MNEs should educate their personnel to focus on quality management with a minimization of waste, and they should also make them aware of the legal and social requirements of institutions and consumers in different markets. MNEs' waste management strategies will not only influence the generation and disposal of waste as an organizational efficiency, they will ultimately impact goodwill and shareholder value. Over a period of time not managing waste may reduce shareholder value, thereby resulting in the decline of the company.

International product stewardship aims to minimize the environmental and social impact and maximize the economic impact of a product till the end of its lifecycle (Lewis, 2005). Both voluntary and regulatory product stewardship promote sustainable products with environmental protection (Rondinelli and Berry, 2000). With regard to international consumers, product stewardship makes consumers rather than the producer pay for the management of waste and does not incentivize the producer to adopt greener designs for its packaging (Lifset, 1993). However, EPR makes producers responsible for controlling waste by implementing strategies that come into action after the end of the lifecycle of a product (Toffel, 2003). It requires producers to determine the most suitable ways locally of managing waste produced by their packaging in different markets using business models that are suitable to their product and the market (Ravi et al., 2005). Like product stewardship, EPR also aims to improve environmental sustainability, but through product design (Mont, 2002). Presumably, EPR moves the responsibility of waste management to the companies and disengages governments or municipalities from the responsibility of managing waste created by products offered by producers (Vergara and Tchobanoglous, 2012). The international implementation of EPRs in developed countries has allowed governments to divert funds otherwise being used for waste management to other needs in their cities (Overby, 2013). EPR makes international producers responsible for environmental externalities and requires them to pay for any building infrastructure required for collecting and recycling waste (Atasu and Wassenhove, 2012). Managers of MNEs incorporate any costs incurred in the sourcing and management of waste into the price of the product paid by the consumer. As a result, environmentally safe products are more expensive. The correlation between price and demand requires product innovation that is green but cost-effective (Gupta, 1995).

As per EPR, the responsibility of managing waste created by the production, supply and consumption of products lies primarily with the company that makes the decisions related to product marketing (Subramanian et al., 2009). Therefore, the strategy for waste management ought to be initiated by the producer, because the producer can control the waste by identifying 
biodegradable packaging that will produce minimum waste and will not be expensive to recycle (Min and Galle, 1997). When the responsibility for managing waste created by product packaging is passed on to managers it penetrates their marketing and operation strategy and encourages them to design recyclable packaging, i.e. packaging that can be recycled easily (Shrivastava, 1995). In its current form, EPR engages the marketing team in the creation of a safer and more economic recycling system of managing waste, by designing packaging that can be used by consumers after consumption. It also motivates the production team to increase its use of environmentally safe products and reduce the consumption of environmentally unsafe products for production (Xie and Breen, 2014).

EPR implementation for MNEs requires producers, and the distributors of their products in different markets, to pay an annual fee for the amount of packaging distributed, based on the type of packaging used by them (Toffel, 2003). This reduces the financial burden on the taxpayer and on the local governments or municipalities. The downside to this is that consumers in international markets end up paying for the recycling cost of packaging (Cahill et al., 2011). Further, international companies charge consumers more for products that do not have a green dot, because disposing of the packaging of these products is even more expensive. Placing a green dot on packaging is an international code for an environmentally friendly packaging practice and indicates that the producer company has made a financial contribution to packaging recovery in the form of a license fee (Short, 2004). Internationally, producers are responsible for providing consumers with clear guidelines on the product label for the disposal of packaging and are expected to provide customers with adequate recycling advice on their labeling, in addition to using a green dot or a Mobius loop or a compostable logo or a European Eco-label or the tidy man or a glass, aluminum, plastic or steel recycling symbol, to reflect their environmental concerns and initiatives. These indicators reveal to the consumer that the manufacturer bears the financial impact internationally for the recovery and recycling of waste of a product (Templeton, 2008). Other initiatives to build zero waste communities include the California Bottle Bill of 1986, which aimed to increase the recycling rate of aluminum, glass, plastic and bimetal containers by charging a redemption fee to distributors on every unit sold by them and engaging retailers who refunded consumers for recyclable packaging received from them. These policies and practices have led to a decrease in packaging waste and the elimination of environmentally harmful packaging material such as blister packaging.

Building zero waste communities requires advanced recycling practices carried out both domestically and internationally by stakeholders, implemented through efficient design created by marketers and material chosen 
responsibly by producers. Zero waste communities can drive product stewardship councils at the local level by targeting products that create environmental concerns and impact local businesses; thereby creating a desire for international companies to be transparent in enforcing their accountability towards product stewardship that reduces public costs through improved product design, in order to improve the sustainability of the environment via the transformation of landfill and other disposal of non-recyclables. The overall framework of EPR requires the active engagement of multiple stakeholders in international markets, i.e. producers, retailers, consumers, national-level administrators, state governments and recyclers. Internationally, producers contribute to sustainability by redesigning packaging and implementing a local recycling strategy. Locally, retailers facilitate the achievement of EPR goals by actively offering green dot registered international products and passing on information received from the producer to the consumer. The consumer also contributes by participating in the recycling process. Governments, too, play an important role outside of the international supply chain by establishing statutory guidelines and regulations, using guiding principles and level playing fields that facilitate the collection and dissemination of information relevant to the sustainable development goal of zero waste communities.

\subsection{CONCLUSION, IMPLICATIONS AND FUTURE DIRECTIONS}

\subsubsection{Conclusion}

The contribution of MNEs to building zero waste communities in developing markets through waste management is very strategic in nature. It requires international managers to have a clear idea of the key drivers that would drive their business strategy - in addition to the strengths, weaknesses, opportunities and threats faced by their business - by incorporating waste management into their business agenda. Based on the analysis of these elements and compliance-related issues, managers of MNEs should consider the operational aspect of their waste sourcing and management strategy in terms of the risks involved versus the opportunities offered. Once the business strategy is formulated - a clear roadmap for field managers with clearly defined objectives - linkages should be created within the global supply chain and training should be organized for initiatives related to the management of waste. Once implemented, every strategy requires regular monitoring of the activities, the communication of goals to the relevant stakeholders and a review of progress at every stage. Simultaneously, 
stakeholders expect MNEs to follow clear practice guidelines while providing quality products with reduced risks, offered with transparency and compliance through processes that are cleaner and more developmental in nature for society overall.

\subsubsection{Implications}

MNEs operating in developing countries adopt practices related to the sourcing and management of waste and extend them into their global supply chain by pushing different actors in the chain to adhere voluntarily to regulatory requirements. Their managers may also link up recycling into product promotion strategies with financial incentives for consumers, and might engage consumers in the recycling process through programs such as bring-back incentives or exchange-old-for-new schemes. The technical aspects of these initiatives when adapted by MNEs in local, meaningful way will involve extra costs, which would be difficult to justify at the initial stage. But the implementation of proposals related to sustainable waste management provides them with access to new business opportunities. If implemented successfully, the role of PPPs, promoted by policy makers to manage waste, would not only build zero waste communities in which everyone could have a very dignified quality of life, but would also lead to a healthy, hazard-free environment for current and future generations.

\subsubsection{Future Research}

There is little motivation for stakeholders to get involved in issues such as zero waste communities. Hence, it is very important to encourage researchers to focus on the environmental aspects of issues such as: guidelines for products that go to landfill and the challenges faced by managers of landfill sites and facilities; the integration of product policy with an assessment and evaluation of a product's lifecycle before it is launched; and other issues such as the conservation of nature and the depletion of the ozone layer. Furthermore, the focus on social issues within firms evolves over time and requires cultural change. Therefore, future research on this topic is highly recommended.

\section{REFERENCES}

Aoki, K. (1992), 'Race, space, and place: The relation between architectural modernism, post-modernism, urban planning, and gentrification', Fordham Urban Law Journal, 20(4), 699. 
Arora, R. (2008), 'Best practices for e-waste management in developing nations', Europe Aid Co-operation Office, 1-24.

Asnani, P. U. (2006), 'Solid waste management', in Urban Infrastructure Report, New Delhi, India: Oxford University Press, 570.

Atasu, A., and Wassenhove, L. N. (2012), 'An operations perspective on product take-back legislation for e-waste: Theory, practice, and research need', Production and Operations Management, 21(3), 407-422.

Bell, F., and Millward, R. (1998), 'Public health expenditures and mortality in England and Wales, 1870-1914', Continuity and Change, 13(2), 221-249.

Boylan, J. W., and Russell, A. G. (2006), 'PM and light extinction model performance metrics, goals, and criteria for three-dimensional air quality models', Atmospheric Environment, 40(26), 4946-4959.

Cahill, R., Grimes, S. M., and Wilson, D. C. (2011), 'Extended producer responsibility for packaging wastes and WEEE - a comparison of implementation and the role of local authorities across Europe', Waste Management \& Research, 29(5), 455-479.

Cetindamar, D. (2007), 'Corporate social responsibility practices and environmentally responsible behavior: The case of the United Nations Global Compact', Journal of Business Ethics, 76(2), 163-176.

Coelho, T. M., Castro, R., and Gobbo, J. A. (2011), 'PET containers in Brazil: Opportunities and challenges of a logistics model for post-consumer waste recycling', Resources, Conservation and Recycling, 55(3), 291-299.

Curran, L., and Ng, L. K. (2018), 'Running out of steam on emerging markets? The limits of MNE firm-specific advantages in China', Multinational Business Review, 26(3), 207-224.

de Araújo, M. C. B., and Costa, M. F. (2006), 'Municipal services on tourist beaches: Costs and benefits of solid waste collection', Journal of Coastal Research, 22(5), 1070-1075.

de Oliveira, C. R., Bernardes, A. M., and Gerbase, A. E. (2012), 'Collection and recycling of electronic scrap: A worldwide overview and comparison with the Brazilian situation', Waste Management, 32(8), 1592-1610.

Dechant, K., and Altman, B. (1994), 'Environmental leadership: From compliance to competitive advantage', The Academy of Management Executive, 8(3), $7-20$.

Delmas, M. A., and Toffel, M. W. (2008), 'Organizational responses to environmental demands: Opening the black box', Strategic Management Journal, 29(10), $1027-1055$.

Fox, T., Ward, H., and Howard, B. (2002), Public Sector Roles in Strengthening Corporate Social Responsibility: A Baseline Study, Washington, DC: World Bank.

Frazzoli, C., Orisakwe, O. E., Dragone, R., and Mantovani, A. (2010), 'Diagnostic health risk assessment of electronic waste on the general population in developing countries' scenarios', Environmental Impact Assessment Review, 30(6), 388-399.

Genovese, A., Lenny Koh, S. C., Bruno, G., and Esposito, E. (2013), 'Greener supplier selection: State of the art and some empirical evidence', International Journal of Production Research, 51(10), 2868-2886.

Goosey, M. (2004), 'End-of-life electronics legislation - an industry perspective', Circuit World, 30(2), 41-45.

Guardian Weblink 1 https://www.theguardian.com/global-development/2013/dec/14/ 
toxic-ewaste-illegal-dumping-developing-countries (accessed on 12 November 2017).

Gupta, M. C. (1995), 'Environmental management and its impact on the operations function', International Journal of Operations \& Production Management, 15(8), 34-51.

Hamlin, C. (1998), Public Health and Social Justice in the Age of Chadwick: Britain, 1800-1854, Cambridge: Cambridge University Press.

Hu, J., Xiao, Z., Zhou, R., Deng, W., Wang, M., and Ma, S. (2011), 'Ecological utilization of leather tannery waste with circular economy model', Journal of Cleaner Production, 19(2), 221-228.

Hume, M. G. (2014), 'Extended producer responsibility as a management practice for waste mattresses in British Columbia', Royal Roads University (Canada).

Jenkins, H. (2006), 'Small business champions for corporate social responsibility', Journal of Business Ethics, 67(3), 241-256.

Kearns, G. (1988), 'Private property and public health reform in England 1830 1870', Social Science \& Medicine, 26(1), 187-199.

Kemp, R., Rotmans, J., and Loorbach, D. (2007), 'Assessing the Dutch energy transition policy: How does it deal with dilemmas of managing transitions?', Journal of Environmental Policy \& Planning, 9(3-4), 315-331.

Koop, S. H., and van Leeuwen, C. J. (2017), 'The challenges of water, waste and climate change in cities', Environment, Development and Sustainability, 19(2), 385-418.

Kuo, T. C., Huang, S. H., and Zhang, H. C. (2001), 'Design for manufacture and design for "X": Concepts, applications, and perspectives', Computers \& Industrial Engineering, 41(3), 241-260.

Lewis, H. (2005), 'Defining product stewardship and sustainability in the Australian packaging industry', Environmental Science \& Policy, 8(1), 45-55.

Lifset, R. J. (1993), 'Take it back: Extended producer responsibility as a form of incentive-based environmental policy', Journal of Resource Management and Technology, 21, 163-163.

Louis, G. E. (2004), 'A historical context of municipal solid waste management in the United States', Waste Management \& Research, 22(4), 306-322.

Mahongano, M. (2017), 'Urban solid waste management in Imphal, Manipur', Journal of Industrial Pollution Control, 33(1), 696-701.

Maleka, T. G., Nyirenda, G., and Fakoya, M. B. (2017), 'The relationship between waste management expenditure and waste reduction targets on selected JSE companies', Sustainability, 9(9), 1528.

Matten, D. (2004), 'The impact of the risk society thesis on environmental politics and management in a globalizing economy - principles, proficiency, perspectives', Journal of Risk Research, 7(4), 377-398.

Milios, L. (2017), 'Advancing to a circular economy: Three essential ingredients for a comprehensive policy mix', Sustainability Science, 13(3), 1-18.

Min, H., and Galle, W. P. (1997), 'Green purchasing strategies: Trends and implications', Journal of Supply Chain Management, 33(2), 10-17.

Mont, O. K. (2002), 'Clarifying the concept of product-service system', Journal of Cleaner Production, 10(3), 237-245.

Ngoc, U. N., and Schnitzer, H. (2009), 'Sustainable solutions for solid waste management in Southeast Asian countries', Waste Management, 29(6), 1982-1995.

Nigh, D., and Cochran, P. L. (1994), 'Issues management and the multinational enterprise', MIR: Management International Review, 34, 51-59. 
Ongondo, F. O., Williams, I. D., and Cherrett, T. J. (2011), 'How are WEEE doing? A global review of the management of electrical and electronic wastes', Waste Management, 31(4), 714-730.

Otles, S., Despoudi, S., Bucatariu, C., and Kartal, C. (2015), 'Food waste management, valorization, and sustainability in the food industry', in C. Galanakis (ed.), Food Waste Recovery, Cambridge, MA: Academic Press, pp. 3-23.

Overby, R. (2013), 'Sitting on their ashes: Why federal regulations should plug the gaping holes in state coal ash disposal regulatory regimes', George Washington Journal of Energy and Environmental Law, 4, 107.

Parashar, C. D. R. (2016), 'Abstracts - Role of analytical sciences in sustainable development', Journal of Integrated Science and Technology, 4(2), 1-23.

Popper, M., Diamond, F., Popper, R., Velasco, G., Van Eynde, S., Ramioul, M., ... and Hölsgens, R. (2017), '4. Sustainable innovation policy advice using a quadruple helix approach to "innovations" mapping', Sustainable Innovation Policy Advice, 27.

Ravi, V., Shankar, R., and Tiwari, M. K. (2005), 'Analyzing alternatives in reverse logistics for end-of-life computers: ANP and balanced scorecard approach', Computers \& Industrial Engineering, 48(2), 327-356.

Reich, M. R. (1995), 'The politics of health sector reform in developing countries: Three cases of pharmaceutical policy', Health Policy, 32(1-3), 47-77.

Rondinelli, D. A., and Berry, M. A. (2000), 'Environmental citizenship in international corporations: Social responsibility and sustainable development', European Management Journal, 18(1), 70-84.

Rugman, A. M., and Verbeke, A. (1998), 'Corporate strategies and environmental regulations: An organizing framework', Strategic Management Journal, 19(4), 363-375.

Rugman, A. M., and Verbeke, A. (2000), 'Six cases of corporate strategic responses to environmental regulation', European Management Journal, 18(4), 377-385.

Rushbrook, P. E., and Finnecy, E. E. (1988), 'Planning for future waste management operations in developing countries', Waste Management \& Research, 6(1), $1-21$.

Sealey, B. J., Phillips, P. S., and Hill, G. J. (2001), 'Waste management issues for the UK ready-mixed concrete industry', Resources, Conservation and Recycling, 32(3), 321-331.

Sharholy, M., Ahmad, K., Mahmood, G., and Trivedi, R. C. (2008), 'Municipal solid waste management in Indian cities - A review', Waste Management, 28(2), 459-467.

Shekdar, A. V. (2009), 'Sustainable solid waste management: An integrated approach for Asian countries', Waste Management, 29(4), 1438-1448.

Short, M. (2004), 'Taking back the trash: Comparing European extended producer responsibility and take-back liability to us environment policy and attitudes', Vanderbilt Journal of Transnational Law, 37, 1217.

Shrivastava, P. (1995), 'The role of corporations in achieving ecological sustainability', Academy of Management Review, 20(4), 936-960.

Silayoi, P., and Speece, M. (2004), 'Packaging and purchase decisions: An exploratory study on the impact of involvement level and time pressure', British Food Journal, 106(8), 607-628.

Singh, D., Zeng, J., Laskar, D. D., Deobald, L., Hiscox, W. C., and Chen, S. (2011), 'Investigation of wheat straw biodegradation by Phanerochaete chrysosporium', Biomass Bioenergy, 35, 1030-1040. 
Spence, R. (2008), Research Councils and Support Organizations in Southeast Asia: A Report on Science, Technology and Innovation Systems in Indonesia, Vietnam, Philippines, Thailand, Malaysia and Singapore, Ottawa: IDRC.

Sthiannopkao, S., and Wong, M. H. (2013), 'Handling e-waste in developed and developing countries: Initiatives, practices, and consequences', Science of the Total Environment, 463, 1147-1153.

Subramanian, R., Gupta, S., and Talbot, B. (2009), 'Product design and supply chain coordination under extended producer responsibility', Production and Operations Management, 18(3), 259-277.

Templeton, N. J. (2008), 'Dark side of recycling and reusing electronics: Is Washington's e-cycle program adequate', Seattle Journal for Social Justice, 7, 763.

Tisserant, A., Pauliuk, S., Merciai, S., Schmidt, J., Fry, J., Wood, R., and Tukker, A. (2017), 'Solid waste and the circular economy: A global analysis of waste treatment and waste footprints', Journal of Industrial Ecology, 21(3), 628-640.

Toffel, M. W. (2003), 'The growing strategic importance of end-of-life product management', California Management Review, 45(3), 102-129.

Tojo, N., and Hansson, L. (2004), 'Political economy for implementing EPR-based policy instruments', OECD Workshop on Economic Aspects of Extended Producer Responsibility.

Tseng, M. L., Tan, R. R., and Siriban-Manalang, A. B. (2013), 'Sustainable consumption and production for Asia: Sustainability through green design and practice', Journal of Cleaner Production, 40, 1-5.

Turunen, T. (2017), 'Deconstructing the bottlenecks caused by waste legislation: End-of-waste regulation', Journal for European Environmental \& Planning Law, 14(2), 186-207.

Vergara, S. E., and Tchobanoglous, G. (2012), 'Municipal solid waste and the environment: A global perspective', Annual Review of Environment and Resources, 37, 277-309.

Vezzoli, C., Ceschin, F., Diehl, J. C., and Kohtala, C. (2015), 'New design challenges to widely implement "Sustainable Product-Service Systems", Journal of Cleaner Production, 97, 1-12.

Weblink $2 \mathrm{http} / / / \mathrm{www}$.europarl.europa.eu/legislative-train/theme-new-boost-for-jo bs-growth-and-investment/file-directive-on-waste.

Williams, P. T. (2005), Waste Treatment and Disposal, Chichester, UK: John Wiley \& Sons.

Xie, Y., and Breen, L. (2014), 'Who cares wins? A comparative analysis of household waste medicines and batteries reverse logistics systems: The case of the NHS (UK)', Supply Chain Management: An International Journal, 19(4), 455-474.

Zeng, X., Yang, C., Chiang, J. F., and Li, J. (2017), 'Innovating e-waste management: From macroscopic to microscopic scales', Science of the Total Environment, $575,1-5$.

Zorpas, A. A., Voukkali, I., and Loizia, P. (2017), 'Socio Economy Impact in Relation to Waste Prevention', in W. Leal Filho, D.-M. Pociovalisteanu, and A. Q. Al-Amin (eds), Sustainable Economic Development, Switzerland: Springer International Publishing, pp. 31-48. 
